\title{
Mediation as a remedy in trust and probate disputes: A review of the comparative approach for international lawyers
}

\section{Zia Akhtar}

\section{Abstract}

Trust and estate law focuses backwards to determine the grantor's intent and which parties are right or wrong under legal precedent. In the law of trusts, mediation is often the route chosen by the parties because it offers the most effective method of resolving disputes which arise when one party has deemed their property to be severed and the trustees are seeking mediation to resolve how assets should be divided. Alternative Dispute Resolution (ADR) generally refers to arbitration and/ or mediation procedures. It offers the disputants an opportunity to circumvent some (or all) of the most complex, ineffective and costly elements of traditional civil litigation. While adversarial litigation is an expensive and very crude zero-sum game for the resolution of disputes, in areas of family relationships, private property and deceased's estate, ADR does not constitute extra-judicial proceedings. An arbitration agreement does not afford a defence to a court action, but entitles a party to apply for a stay of proceedings, under section 9 of the UK Arbitration Act 1996. This paper draws on UK and US examples and argues that facilitative mediation in trust disputes is especially suitable for ADR in contentious trust cases. It also considers whether the UK and Ireland could usefully adopt some of the US's more developed and structured practices on ADR and mediation.

Key words: ADR, Mediation, Estate planning, Trustee Act 2000, Saunders v Vautier, Uniform Mediation Act 


\section{Introduction}

Trust and estate advisors are aware of the unprecedented growth in inheritance litigation in recent times. The alternative dispute process of mediation is well suited to contentious probate disputes, and particularly those relating to secession, as mediation offers the possibility of a resolution within a shorter timescale and for a lower cost than litigation. ${ }^{1}$ The traditional contentious probate disputes, for example whether a will was properly executed or over its construction, are probably the least well suited to mediation because they require a confirmed beneficiary.

For disputes over the validity of a will (whether the testator had capacity to make it or was unduly influenced for example) or disputes under the Inheritance Act, mediation is ideal. These are legally and factually complex cases, often requiring long drawn out litigation with submissions that need longer preparation time and adjournments before they come to trial.

Three types of mediation that exist in parallel with the courts in common law courts can be identified: (i) facilitative mediation where the mediator "facilitates negotiations" among the parties to a dispute, with the goal of reaching a durable settlement which addresses their requirements, (ii) evaluative mediation, where an expert in a field, after hearing both sides of the dispute, considers the respective parties' possibilities of success in litigation and advises more "realistic expectations which encourage settlement", and (iii) transformative mediation where the main goal may "not necessarily be to reach an agreement" but the primary goal is for the parties to supervise the process and its conclusion, with the mediator as a guide "offering procedural and substantive suggestions" (Friedman, 2016).

\footnotetext{
${ }^{1}$ The proceedings can be commenced in the Chancery Division, the Family Division or the County Court, frequently using the Part 8 procedure rather than the more usual Part 7 process. There are no costs imposed on the other party although of course the court always has discretion to impose this, particularly where there are significant factual disputes.
} 
The application of mediation in trust and estate disputes is geared to maintain privacy in the case of an asset transfer dispute which is necessitated by the revocation of trusts (Madoff 2002). There is a reason for individuals to create objectives in these types of trusts, namely to avoid a probate court proceeding and to maintain the family's privacy. If litigation was commenced, the trust could become a matter of public record and its terms could be divulged, undermining the grantor's intention of protecting the family's deeds that contain the trust instruments.

This paper discusses facilitative mediation in which the process is designed to help the parties achieve a settlement out of court. It will consider the obstacles that arise and how these can impede the progress of a mediation. This will be discussed in the context of English case law, referring to decided cases and the statutory framework. The discussion will include a comparative approach that reflects on how mediation works in the US and how it has been adopted there so as to facilitate or compel parties to adopt a mechanism using non-litigious proceedings in disputes that concern trust and probate law. We will also consider whether US practices could be usefully adapted for UK and Irish use.

\section{Contentious disputes in ADR mediation}

It is assumed that the fundamental basis of a trust or will that transfers assets is a unilateral conveyance to the office of trustee or executor for the benefit of, and on behalf of, third party beneficiaries. ${ }^{2}$ The issue is whether it is possible to mediate in trusts disputes and whether this approach can be considered in all cases.

A common feature of Inheritance Act disputes is that they involve many parties. It is usual to issue notices against all beneficiaries, and this can amount to a large number of people who may well all propose, or need, separate representation. The common law has long recognised that the trustee has a

\footnotetext{
2 It does not matter that an arbitration clause (like a trustee-charging clause in a trust deed) is not contractual so long as it is an agreement which makes it binding.
} 
general duty to keep beneficiaries informed about trust administration and this duty is considered necessary to give the beneficiaries enough information to protect themselves from potential breaches of the trustee's fiduciary duty. ${ }^{3}$

Traditional contentious probate disputes, over whether a will was properly executed or over how it was constructed, are not appropriate for mediation because they are usually zero sum cases. Even in these circumstances, both parties have much to lose in litigation, and it may well be advantageous for disputants to reach a settlement rather than to face the risk of losing their share in the property. If the matter enters the court then there is an uncertainty and the risk that, as a result of the proceedings, an asset may be transferred to another party. The fact that parties may be ordered to pay costs is a further disadvantage of litigation. ${ }^{4}$

The parties to a dispute in trust or estate matters may contract into an acceptable form of ADR which does not afford a defence to a court action, but entitles a party to apply for a stay of the action, under section 9 of the Arbitration Act 1996. The Chancery Court retains its supervisory and facilitative jurisdiction over the procedure. It is also the forum for appeal, and assists parties in the enforcement of settlements and awards. The successful resolution of a trust or probate dispute by arbitration or mediation requires a provision, or agreement, for ADR does not oust the jurisdiction of the court and an arbitration clause that constitutes an agreement to arbitrate and/ or mediate is binding on all necessary parties to the dispute. ${ }^{5}$ The proper representation of all interested parties (including unascertained, unborn and prospective beneficiaries) will undertake the

\footnotetext{
${ }^{3}$ However, there has been significant disagreement among jurisdictions about which beneficiaries are owed the duty to inform, how to comply with the duty, and how to balance some trustees' desire to keep a trust secret from the beneficiaries with the concern that a secret trust may leave beneficiaries' interests vulnerable (Ruce 2011).

${ }^{4}$ Seagrove v Sullivan [2014] EWHC 4110 (Fam) was a trust case in which there was a dispute over the ownership of property worth $£ 1$ million. There was no deceased party but the costs amounted to $£ 1.3$ million. The Judge considered these costs to be excessive and ordered the parties to significantly reduce the amount of documentary evidence at trial, and the matter was settled within a day.

${ }^{5}$ David Hayton states that a settlor has the power, on behalf of himself and the beneficiaries, to refer any dispute to arbitration or mediation. The beneficiaries are held to derive their interests through the settlor and this is expressly set out in his or her trust deed with the trustee (Hayton, undated).
} 
dispute to be arbitrable, or otherwise capable of being resolved by binding agreement and/ or order between those participating in the ADR process. ${ }^{6}$

There is an implied theory that advances the principle of 'deemed acquiescence' in mandatory ADR provisions in trust instruments on the part of beneficiaries in which they claim from a trust settlement through the settlor, who can be a party to the agreement with the trustee for ADR. Thus, the beneficiary must be taken to accept the arbitration agreement, because an agreement to arbitrate all matters arising from a connection with the trust is a condition precedent to benefiting from the trust (Cohen, 199).

The submission to arbitration by trustees has long been authorised in English law by codifying the common law of arbitration in the Determining Differences by Arbitration Act 1698. ${ }^{7}$. The Trustee Act 1893 gave statutory effect to the common law rule by permitting trustees to submit claims in favour of or against the trust estate to arbitration. The Trustee Act 1925 section 15 has broadened scope of arbitrability of trust disputes.

In Re Earl of Strafford ${ }^{8}$ it was held that 515 of the Trustee Act 1925 gives trustees and personal representatives wide discretion in settling claims by or against the trust or estate. It also protects trustees and personal representatives from loss caused by anything done in the exercise of their powers under this section, provided they have acted in good faith and after properly considering the issues involved. In cases of doubt or difficulty, the trustees or personal representatives can apply to the court under s15 of the Trustee Act 1925 to sanction any compromise they propose.

The exercise of this power is subject to the statutory duty of care under the Trustee Act 2000. Section 1(1) provides that, whenever the duty of care applies to

\footnotetext{
${ }^{6}$ Section 82(2) of the 1996 Act further provides that a party to an arbitration agreement includes any person claiming 'under or through' a party to the agreement. This allows the unborn or unascertained beneficiaries to enter into an agreement.

${ }^{7}$ The arbitrability of a dispute between trustee and beneficiary was considered in England in Auriolv Smith 37 Eng Rep 1041 (1823).

8 [1979] 2 WLR 459 CA
} 
a trustee, he or she must exercise such care and skill as is reasonable in the circumstances, having regard in particular to any special knowledge or experience that he or she has or holds themself out as having and, if he or she acts as a trustee in the course of a business or profession, to any knowledge or experience that it is reasonable to expect of a person acting in the course of that business or profession. ${ }^{9}$

Section 35(1) of the Trustee Act 2000 applies to personal representatives administering an estate in the same way as it does to trustees managing a trust. The trustees and personal representatives, as a matter of course in the administration, may not incur costs for the estate by engaging in litigation without authority. Under the principles established in the case of Re Beddoe Downs v Cottam $^{10}$, the same principles apply to ADR and, unless all beneficiaries are sui juris (not legally competent to manage their own affairs) and agree to ADR, the court's authority should be sought. The proceedings seeking such authority are commonly known as Beddoe applications which are a part of procedure in the Chancery Division. Under such applications trustees are allowed to obtain the consent of the court to expend trust funds on ADR. The court has power to join in the Beddoe proceedings any party (including non-beneficiary parties) with an interest in the outcome of the application.

There are occasions when the 'other party' may be a beneficiary of the trust who is in dispute with the trustee or with other beneficiaries against whom it is proposed to conduct or defend the ADR proceeding. In such circumstances Beddoe relief may still be appropriate, as will the procedure outlined in Re Moritz $(\text { decd })^{11}$, the beneficiary against whom proceedings may be initiated can be joined as a party to the Beddoe application. However, the evidence upon which the court will be required to evaluate the strength of the claim against the beneficiary will not be served upon them and they will not be entitled to be present when the merits of that claim are debated before the court. At times the directions can be

\footnotetext{
${ }^{9}$ Schedule 1, paragraph 4, applies the duty of care to a trustee when exercising power under s.15 Trustee Act 1925 to do any of the things referred to in that section. 
dealt with on paper without a hearing and there are provisions for the directions hearing to be held in private.

The English courts apply the rule in Saunders v Vautier ${ }^{12}$, under which beneficiaries who are together absolutely entitled to the property subject to the trust or the will, may bring the trusts to a conclusion or direct the trustees or personal representatives as to the execution of the trusts, without the intervention of the court. Where the parties participating are sui juris (not legally competent to manage their own affairs), this is basis for the settlement of trust and probate disputes by ADR. The possibility also exists for a variation of trusts under the Variation of Trusts Act 1958.

Section 1 of the 1958 Act provides the 'benefits test' for the determination by the court of any application by the beneficiaries for property held on trust, under any will, settlement or other disposition. Under this Act, the court cannot approve an arrangement on behalf of any person under sub-sections (a) or (b) or (c) unless the carrying out thereof would be for the benefit of that person. This has been interpreted broadly in case law in re Remnant's Settlement Trusts ${ }^{13}$ and Pennycuick J held that the concept of "benefit" is not confined to financial benefit but that the court is entitled, and bound, to consider benefit of any other kind. In re Michelham's Will Trusts ${ }^{14}$, Buckley J ruled that, when looking at the scheme and the probable events as a whole, the scheme under consideration would confer a benefit on possible unascertained or unborn beneficiaries. Therefore, the scheme was one which the court would approve.

The presumption after these judgments is that the court has powers to approve variations, by statute and under its inherent jurisdiction, to approve an agreement to submit a dispute to ADR, and to accept any settlement agreement as binding. This principle could also extend to fix a clause for arbitration or mediation, in an appropriate case, for compulsory provisions into a trust or will to

\footnotetext{
12 (1841) Cr \& Ph 240

13 [1970] 2All ER 554

14 [1964] 1 Ch 550
} 
govern future disputes. The mechanism could override the objection of one party if their intention is to litigate before the process for settlement has been exhausted.

\section{Facilitative mediation in chancery and probate disputes}

The court has the power to give consent to unborn and/ or unascertained beneficiaries or to be put to an election, or be deemed to have been elected in equity. The doctrine of election in trusts implies that "a person who accepts a benefit under an instrument must adopt the whole giving full effect to its provisions, and renouncing every right inconsistent with it" ${ }^{15}$. Even if not, the court can consent on their behalf to an agreement to resort to ADR in relation to any particular dispute, and to any resulting resolution of a dispute.

Teresa Rosen Peacocke draws a nexus between mediation and the principles that govern trust and testamentary instruments by elucidating the concept of the equitable doctrine of election. This has assumed that there is a beneficial entitlement to consensus in reaching an agreement about the direction of the trust. ${ }^{16}$ This concept implies that no one shall both "approbate and re-probate" 17 which means in effect that the claim is both under and in opposition to the same instrument. Rosen Peacocke states that a person who elects to take under the will must confirm, so far as he or she is able, the whole instrument which may be seen as constituting an implied agreement under the ADR clause, or as creating an obligation to enter into an agreement for this purpose and in the terms of the clause contained in the trust deed or will, in relation to any dispute falling within the scope of the clause (Resen Peacocke, undated).

\footnotetext{
${ }^{15}$ Re Macartney [1918] 1 Ch 300.

${ }_{16}$ The doctrine was formulated by Lord Hatherley in Cooper v Cooper (1874) LR 7 HL 53 as "The equitably duty which the law imposes on a person claiming under an instrument, of giving full effect to it, as far as it would be otherwise ineffective, except through his concurrence ... [or] by ... abandoning all his interest under the will ..." at $\mathrm{p} 70$

${ }_{17}$ As explained by Sir Christopher Slade in the Privy Council case (on appeal from the Court of Appeal of the Cayman Islands) in Cleaver v Delta American Reinsurance Company [2001] UKPC 6.
} 
It may be possible to avoid litigation if the trustee - some other appointee such as a protector or enforcer - is given the power to amend the trust instrument, rather like the practice of pension trustees' powers to amend the trust instrument so as to promote the best interests of the beneficiaries as a whole. ${ }^{18}$

The probate and chancery courts in the UK, like courts in the US, have inclined towards intra-family settlement of trust and estate disputes being solved by mediation rather than through litigation. As a result of the family settlement doctrine, courts generally uphold such agreements in the absence of fraud, undue influence or the breach of a confidential relationship (Radford 2000).

Mediation can be utilised at any time in trust or estate administration, whether or not a conflict is already being litigated. It should be considered if the trustee and advisors are unable to resolve a dispute informally and administration has reached deadlock.

The most creative uses of mediation begin in the estate planning phase to avoid an ultimate dispute over issues such as the disposition of a family business or how to devolve property in a second marriage where there are stepchildren (Schwartz, 2004). The parties might benefit by the early use of mediation to formulate a solution with the assistance of an estate planning attorney who is comfortable addressing delicate non-tax issues (Gage et al, 2004).

In the US, the federal district courts can also require parties to mediate disputes under a power granted by section 652 of the Alternative Dispute Resolution Act ( 28 USC). Most states have enacted the Uniform Trust Code ('UTC') that includes Section 111(b) authorising non-judicial settlement agreements with respect to trust matters, subject to certain requirements and definitions. ${ }^{19}$ There are some states, such as Texas, California and Florida, that have comprehensive

\footnotetext{
18 The settlements of trust and probate disputes involving representative parties require the approval of the court. The CPR Part 19.7 refers to a claim and specifically permits an order to be made before any action is brought. 19 The UTC has been enacted in Alabama, Arizona, Arkansas, District of Columbia, Florida, Kansas, Maine, Massachusetts, Michigan, Missouri, Montana, Nebraska, New Hampshire, New Mexico, North Carolina, North Dakota, Ohio, Oregon, Pennsylvania, South Carolina, Tennessee, Utah, Vermont, Virginia, West Virginia, and Wyoming. UNIF. LAW COMM'N, Legislative Fact Sheet-Trust Code, http:/ /www.uniformlaws.org/LegislativeFactSheet.aspx?title=Trust\%20Code (last visited Aug. 18, 2014).
} 
statutes governing the practice, while a majority of states, including Illinois, do not because they have court-annexed mediation. ${ }^{20}$ This is a more efficient and speedier form of justice where cases are referred from court to the mediation as procedural necessity.

The Illinois Supreme Court Rule 99 authorises each circuit court to establish its own procedure and impose its own set of rules upon the process and it consists of a list of matters to be addressed in each circuit's local rules for a mediation programme. It grants the mediator the equivalent of judicial immunity. ${ }^{21}$ The State of Illinois has also adopted the Uniform Mediation Act, which is binding but may be modified by agreement.

Confidentiality is a critical aspect of mediation and is addressed by the Uniform Mediation Act ('UMA'). ${ }^{22}$ There are clauses included that provide "[ $t$ ]he court may submit [disputes] to mediation, case evaluation, or other alternative dispute resolution process," or even more generally, "explor[e] the use of Alternate Dispute Resolution (ADR) processes." 23

Washington State, however, has adopted specific provisions as part of the Trust and Estate Dispute Resolution Act ('TEDRA') in 1984 and this was last revised in 2008. This grants "any party the right to proceed first with mediation and then arbitration before formal judicial procedures may be utilized," and provides detailed directions for arranging mediations and arbitrations. ${ }^{24}$ The framework of TEDRA also provides for parties to come to an agreement regarding the will, trust or other related matter which may be a radical alternation from what the testator or settlor intended, or even embodying provisions that the testator or settlor expressly intended to exclude. ${ }^{25}$ This is similar to the rule in Saunders v Vautier because it allows the beneficiaries to reach private settlements of disputes, outside of any court supervision, overriding the terms of the will or trust. The

\footnotetext{
${ }^{20}$ See http:/ / CourtADR.org for the ADR Resource Center established by Resolution Systems Institute ("RSI").

21 ILCS S. Ct. Rule 99 (West 2016).

${ }^{22}$ Uniform Mediation Act ('UMA') (Nat'l Conference of Comm'rs on Unif. State Laws 2001, amended 2003).

23 UMA SS 3-6; 710 ILCS 35/3 -710 ILCS 35/6.

24 Washington Re Code 1811.96A 010

25 Idaho adopted its own version of the Code in 2006.
} 
framework of TEDRA has been criticised for permitting parties to undo elaborate estate plans and infringe on the testators intentions in creating the trust. ${ }^{26}$

There are standard clauses in mediation agreements in the US which are part of estate planning and testamentary documents which encourage trust and estate mediation. These require different considerations from those for arbitration clauses where the parties may forfeit rights otherwise available, including the right to appeal the arbitrator's decision. There are no similar issues with mandatory mediation clauses and the parties may be required to mediate, but the decision whether to settle and the outcome of the dispute is always determined by the parties.

These clauses can be contrasted with the precatory clauses which are mainly applied in wills and trusts, and a standard mediation clause might request that in a hypothetical dispute a party make good faith efforts to resolve a dispute out of court through mediation. This will be in accordance with the testator's wishes such as, for example: "I request, but do not require, that persons asserting a claim to or against my estate agree to make a good faith effort to resolve any disputes about the distribution of my estate through mediation" (Love and Sterk, 2008).

The benefits of facilitative mediation is that the attorney contributes by due diligence in preparation and acts as counsellor in the case. The process is similar to litigation and he needs to know the facts, and the law regarding the case and then he has to design a plan, the strategy and tactics of the process in order to prepare the written advocacy submission, in the form requested by the mediator. This requires a Mediation Preparation List to be drawn up which could act as an appendix to the documents submitted with the case notes to the mediator (Klein, 2008).

Lee J ay Berman designates to the attorney the responsibility to advise the mediator of the strengths of the client's case and also to advise the mediator of

\footnotetext{
${ }^{26}$ For a more nuanced discussion see Mantner et al (2009) 
the results of previous negotiations and any previous offers. The attorney, as the advocate in the case, must also make effective use of any confidential private meetings that they hold with the mediator. They must be transparent in the inquiries they make of mediator. They must also suggest what they see as the best methodologies which may be used to negotiate effectively on behalf of their client (Berman 2009).

The major points that the attorney needs to be aware of so as to facilitate mediation for his client include crucial issues such as "Develop and test settlement proposals with the mediator" and "Seek the mediator's assistance in breaking impasse". The attorney also needs to advocate that the facilitative mediator may need to "further reality test the parties so that they have a better understanding of the downsides of litigation and the reason for continuing settlement discussions rather than walking away" (ibid).

There is an inter-relationship between the facilitative mediation, trust cases and ABA Rules of Professional Conduct that prohibits attorneys from representing multiple clients where there is a conflict of interest. ${ }^{27}$ There is a possibility of the parties selecting separate counsel because the estate or trust issues are contentious and there may be many lawyers present at the meeting. The legal representatives may concur in introducing a mediator to facilitate such a meeting. There will not be a breach of the Model Rules because the mediator is not representing any clients and not subject to the same constraints in raising necessary issues which might impact adversely on one or more parties in the case.

The mediator's proceedings will be privileged under the Uniform Mediation Act and the requirement for mediation confidentiality among the parties may

\footnotetext{
${ }^{27}$ Model Standards of Conduct for Mediators adopted by the American Bar Association Section of Dispute Resolution, the Association of Conflict Resolution and the American Association of Arbitration, are the ethical guidelines applicable to all mediators, including attorney-mediators, but do not include enforcement procedures and are not binding. See Model Standards of Conduct for Mediators adopted by the ABA House of Delegates in August, 2005, available at http://www.americanbar.org/content/dam/aba/migrated/dispute/documents/model _standards_conduct_april2007.authcheckdam.pdf
} 
protect conferences which would not otherwise be bound by the attorney-client privilege. ${ }^{28}$

\section{Conclusion}

There needs to be a more informed approach by parties in contentious disputes which would enable them to adopt mediation in trust and probate cases. The recourse to litigation should be avoided in order to save costs, time and exposure in matters that are private and often concern family estates and the division of assets. In these circumstances where facilitative mediation is appropriate, the process of ADR should begin. The legal representative can act proactively in order to counsel, prepare documentation and be an intermediary between the client and the mediator. This is facilitative mediation that will 'benefit' the client and enable the fiduciary relationship to be maintained in contentious matters and where the administration of the trust is involved.

There are certain aspects of dispute resolution in trusts that are not compatible with facilitative mediation. In such circumstances, disputes may require litigation. This is particularly true when, for example, there is a question about the validity of a will that cannot be mediated and needs to be adjudicated. Litigation may also be the best solution where a dispute involves an incapacitated beneficiary or where a power imbalance otherwise exists between the parties and accommodations must be made. If this happens then the weaker party must be adequately protected in the ADR process, whether by the court, by a courtappointed special representative or guardian ad litem (where somebody is appointed to act on behalf of a child or a person the court does not consider able to represent themselves), through parental representation, by a virtual representation statute, or otherwise. There are also other exclusions such as factspecific disputes like those involving trustee fees or asset valuations. These might

\footnotetext{
${ }^{28}$ Illinois Model Rule of Professional Conduct 1.7 provides that "without a client's informed consent, a lawyer may not represent a client if that representation will be 'directly adverse' to another client or will 'materially limit' the lawyer's responsibility to another client, a third person, or the lawyer's own interests." ILCS S Ct Rules of Prof. Conduct Rule 1.7 (West 2016).
} 
be more efficiently resolved by either arbitration or by evaluative mediation rather than facilitative mediation.

The US example shows that there needs to a more co-ordinated process in mediation in law that moves away from the traditional mediation towards facilitative mediation which provides a consensual, non- binding, confidential process overseen by a third-party neutral mediator(s). The American system is more conducive to the early settlement of disputes because there is a procedure whereby lawyers accept their need to get involved as part of their obligations to their clients. It has a more uniform structure and which makes available a list of qualified professionals who can be part of the process. This structure leads to greater certainty and a more effective resolution of disputes within an equitable framework of trusts and probate disputes.

\section{References}

Berman, L.J . (2009), "12 Ways to Make Your Mediator Work Harder for You," Advocate Magazine (October 2009).

Cohen, L. (1999), "The Arbitration of Trust Disputes Vol 7 (1999)" J ournal of International Trust and Corporate Planning, at 203.

Friedman, R.L. (2016), Keeping trust and estate disputes out of court: An Estate Planner's Guide to Mediation, Annual Trusts \& Estates Seminar November 11, 2016, CH. 3 Page 1

Gage, D., Gromala, J. and Kopf, E. (2004), Holistic Estate Planning and Integrating Mediation into the Estate Planning Process, 39 Real Prop. Prob. \& Tr. J . 507.

Hayton, D. (undated), Problems In Attaining Binding Determinations of Trust Issues By Alternative Dispute Resolution,

http:// www. kozlaw. com/ think/ handouts/ Hayton\%20ADR\%20Paper. pdf.

Klein, K.K. (2008), Representing Clients in Mediation: A Twenty-Question Preparation Guide for Lawyers, 84 N.D. L. Rev. 877.

Love, L.P. and Sterk, S. E. (2008), Leaving More than Money: Mediation Clauses in Estate Planning Documents, 65 Wash. \& Lee L. Rev. 539, 578. 
Madoff, R.D. (2002), Lurking in The Shadow: The Unseen Hand of Doctrine in Dispute Resolution, 75 So. Calif. Law Rev. 161.

Mantner,G.E. and Orr, H.L.G. (2009), A Brave New World : Non-J udicial Dispute Resolution Procedures Under the Uniform Trust Code and Washington and Idaho's Trust and Estate Resolution Acts, ACTEC J ournal, 35, 159-186

Radford, M. F. (2000), An Introduction to the Uses of Mediation and Other Forms of Dispute Resolution in Probate, Trust, and Guardianship Matters, 34 Real Prop. Prob. \& Trust J . 601 at 645.

Rosen Peacocke, T. (undated), Arbitration and Mediation of Trust and Probate Disputes: Obstacles Removed (or Non-Existent) 23/8/15 https:/ / www. lexology.com/ library/ detail. aspx?g=84965cde-61af-49e1-b88fad6d43e9e88e

Ruce, P.J . (2011), The Trustee and the Remainderman: the Trustee's Duty to Inform, 46 REAL PROP. TR. \& EST. L.J . 173.

Schwartz, S. (2004), Family Business Litigation: The Remedy Can Be Worse Than the Malady, 61 Bench \& Bar Minn. 40 (April).

Zia Akhtar LLB (Lon), LLM (Lon), Member of the Honourable Society of Grays Inn, Sussex University, specialising in ADR law and in Mediation process. 